\title{
Analysis of monetary regulation of the investment sphere in the Republic of Belarus
}

\author{
Marina Zelenkevich ${ }^{1, *}$ and Natallia Bandarenka ${ }^{1, * *}$ \\ ${ }^{1}$ School of Business of Belarusian State University, 7 Oboinaya Str., Minsk, 220004, Belarus
}

\begin{abstract}
The purpose of the article is to substantiate the possibility and necessity of the central bank's monetary policy to stimulate investment and economic growth for developing economies on the example of the investment sphere and monetary policy in Belarus. It was determined that the impact of monetary regulation on investment and economic growth is achieved in the course of the central bank's activities to maintain indicators of price and financial stability which reflect favourable conditions for investment. Price stability is achieved through the implementation of various central bank strategies such as targeting the exchange rate, money supply and inflation. These strategies are defined as the objectives of monetary policy. The article discusses the advantages of monetary regulation in comparison with fiscal regulation, and also contains an analysis of its practical implementation in the Republic of Belarus in the period 2000-2019. As a result of the study the economic and financial results of the strategies applied at different stages were determined, their consequences for the economy were substantiated, and the strategies that best affect the financial and economic indicators in the country were identified. For countries with a small open economy which includes Belarus maintaining price and financial stability is complemented by a set of measures to reduce the devaluation expectations of market entities and create a favorable foreign economic environment.
\end{abstract}

\section{Introduction}

The main driver of innovative economic growth is investments that help maintain the country's competitiveness in the context of unstable development. To the global threats of climate change, environmental and demographic problems, poverty, terrorism and others, new challenges are added which also significantly affect the investment decisions of market actors and, accordingly, economic development. We are talking, in particular, about the new challenge of the XXI century - the COVID-19 pandemic which since the beginning of 2020 has acquired a global scale and devastating consequences for the world economy. According to experts from international organizations the fall in world GDP in 2020 amounted to 3-5\% which is stronger than in the crisis year of 2009 , when it reached $1.3 \%$. Today traditional investment promotion instruments are no longer sufficient or effective. One of the urgent problems of the modern economy characterized, on the one hand, by globalization and integration, and, on the other hand, by high risks is the search for new ways to achieve its stable growth. In this regard scientific research is being updated to substantiate the transformation of approaches to determining ways to effectively implement the investment process, substantiating the methods and tools for its regulation taking into account new realities.

Monetary regulation of economic processes is actively used in world practice mainly for solving short-term prob-

\footnotetext{
*e-mail: marina.zelenkevich@gmail.com

**e-mail: bondnata@mail.ru
}

lems of countercyclical policy. Target orientation of monetary regulation to stimulate investment and economic growth, i.e. the solution of structural, long-term problems from monetary instruments is still the subject of scientific controversy among economists and financiers. The research presented in the article corresponds to the following scientific directions of the conference: monitoring, modeling and forecasting in the banking sector and the dynamics of emerging markets in the crisis and post-crisis period. The subject of the analysis is to determine the features and problems of the investment sphere development in Belarus in crisis and post-crisis periods, as well as to substantiate the place and significance of monetary methods for stimulating investment in the system of state management of the economy.

Scientific works of scientists such as J.M. Keynes [1], J.R. Hicks [2], M. Friedman [3], F.S. Mishkin [4], P.A. Samuelson [5], J. Tobin [6] and others are devoted to identifying characteristics investments, forms and methods of their regulation, including financial and monetary regulation. The most famous works of Belarusian and Russian scientists in which the investment process and methods of its regulation in developing economies are analyzed belong to E.B. Dorina [7], V.N. Shimov [8], S.Yu. Glazyev [9], L.N. Krasavina [10], A.L. Kudrin [11], S.R. Moiseev [12], V.N. Shenaev [13] and others. These scientific works substantiate certain areas of financial and monetary regulation of investments, as well as their impact on economic development. This is mainly research on the strategy and tactics of implementing economic, in- 
novation and social policies using the potential of national financial and credit systems. However, there are no substantiated scientific approaches to determining the forms and directions of the banking system's impact on the investment process in a developing economy which creates obstacles to optimizing the methods and sources of investment growth taking into account its specifics. This does not allow adapting the existing theoretical and practical studies of monetary regulation of the investment process to the modern conditions of its implementation taking into account the increased external and internal risks.

The scientific literature presents studies of some directions of the influence of monetary policy on investment. A feature of emerging economies is the proof of the limited investment bank lending to the economy. The reasons for this situation are substantiated in some scientific works [14]. These include the following:

- Second-tier banks cannot concentrate and provide loans in an amount greater than the current state of the economy allows. This is determined by the low degree of monetization of the economy the indicator of which is the ratio of the monetary aggregate to GDP. The highest values of the monetization indicator are observed in the developed countries of Europe (from 86 to $116 \%$ ). In the countries of Central and Eastern Europe the level of monetization ranges from $20.8 \%$ in Serbia to $84.6 \%$ in Bulgaria. In the CIS countries this indicator has a lower value and varies from $15.4 \%$ in Belarus to $44.6 \%$ in Russia [15];

- Due to the specifics of the emerging economy not all free funds go to banks (for example, economic agents keep part of their money in the form of cash);

- The long-term nature of the resources attracted by banks does not always depend on the banks themselves: this parameter, first of all, is set by the inflationary and devaluation expectations of economic agents, the level of their income and other economic and psychological factors;

- The money supply in circulation should be provided with competitive goods and services demanded by national financial assets as a store of value.

Thus, the noted features of the monetary sphere in developing economies limit the possibilities of monetary expansion as a basis for growth and often have the opposite effect expressed in the of inflation growth.

\section{Analysis of the investment sphere in the Republic of Belarus}

The relevance of the search for new forms and methods of investments regulation in the Republic of Belarus is confirmed by the presence of problems that exist in the investment sphere of the country. Figures 1 and 2 provide information characterizing the investment process in Belarus from 2010 to 2019 [16, 17].

The data in figures 1 and 2 shows that the share of fixed capital investments in GDP decreased from 32.5\% in 2010 to $21 \%$ in 2019 . At the same time, the growth

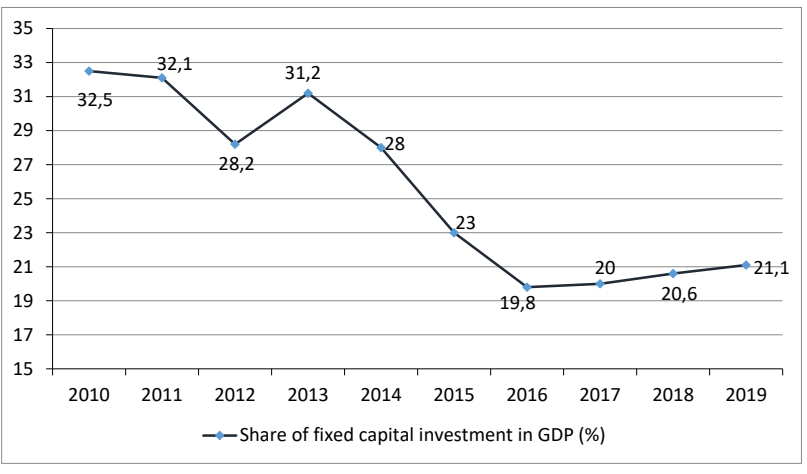

Figure 1. Share of fixed capital investment in GDP in Belarus

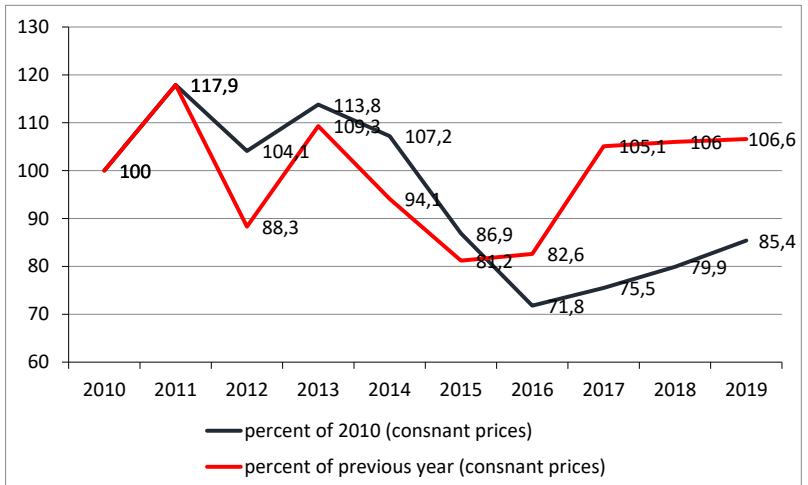

Figure 2. Growth rate of fixed capital investment in Belarus

rates of fixed capital investments over 9 years increased slightly by $5 \%$; and in certain periods $(2012,2015-2016)$ had negative values.

Along with the negative trends characterizing the investment sphere in Belarus, it should be noted that there was a positive trend in attracting foreign investment to the country in the period from 2002 to 2019 (figure 3). In some time intervals a decrease in foreign investment was observed, for example, from 2012 to 2016 which was associated with the crisis in the Belarusian foreign exchange market in 2011 and 2014. By 2017 the volume of foreign investment began to grow gradually reaching the level of 2015 [18].

In the structure of foreign investments the main share is occupied by direct investments in the real sector and their volume during the analyzed period increased almost 2 times. Portfolio investments, on the other hand, occupy an insignificant share in the total volume of investments: their annual volume is less than $1.0 \%$ during the analyzed period (figure 4) [18].

The volume of other investments during the analyzed period increased until 2006 and in the subsequent period had an almost constant downward trend. Other investments include: trade credits (prepayment for exports and provision of loans or exports); loans received from international financial organizations; bank deposits (these include own accounts of foreign legal entities in Belarusian banks (investments in Belarus from abroad) and Belarusian legal entities in foreign banks; receivables and payables related 


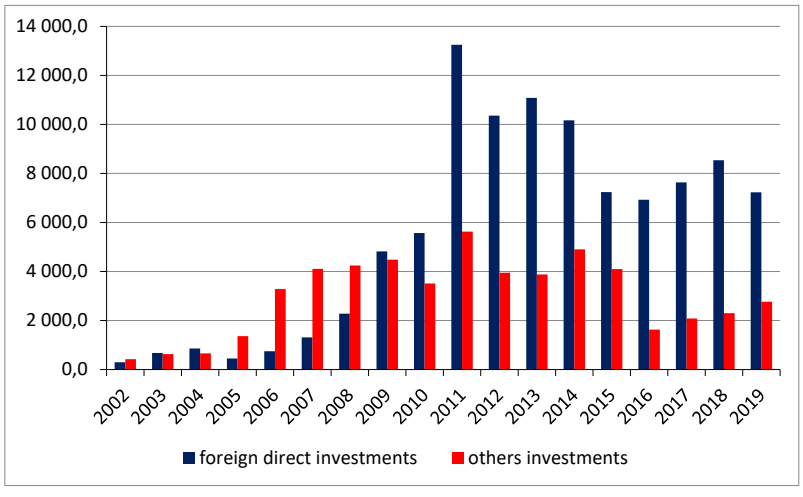

Figure 3. Foreign investment in real sector of the economy in the Republic of Belarus (million US dollars)

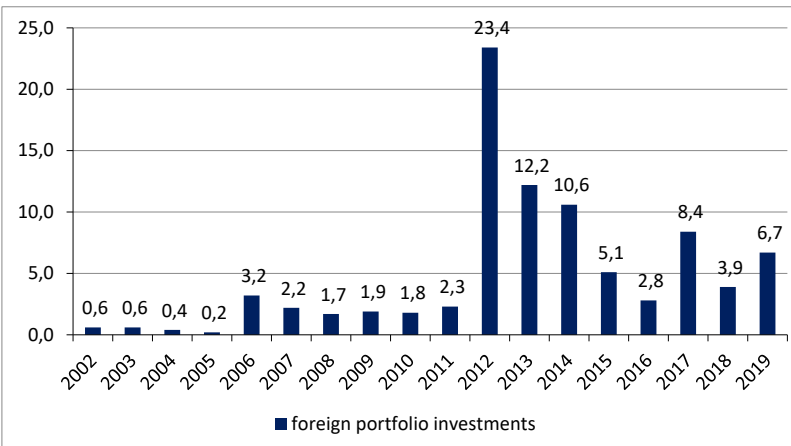

Figure 4. Foreign portfolio investment in Belarus (million US dollars)

to overdue interest payments, etc. A feature of the investment sphere of Belarus is the formation of investment resources mainly due to internal gross savings.

In the structure of investment resources organizations' own funds are in first place, and their share has practically not changed over the analyzed period: in 2005 it was $44.0 \%$, and in $2019-40.6 \%$. In second place by sources of financing are bank loans (13.6\% in 2019), in third and fourth places are funds from the republican budget and savings of the population (11.4\% and $10.4 \%$ in 2019. At the same time the share of budgetary funds remained practically unchanged while the share of population funds increased from $7.9 \%$ in 2005 up to $10.4 \%$ in 2019 [19].

Analysis of fixed capital investment by type of ownership showed the following trends. Despite the significant share of the state budget in the structure of investment resources their share as consumers of investment decreased from 50\% in 2010 to $39.0 \%$ in 2019 [20]. At the same time the shares of private and foreign organizations in fixed capital investment are steadily growing (table 1 ).

From the data presented in figure 5 it can be seen that the organizations' own funds significantly exceed other sources of investment. In the structure of external sources a significant share is taken by bank loans followed by household savings and budget financing [20].

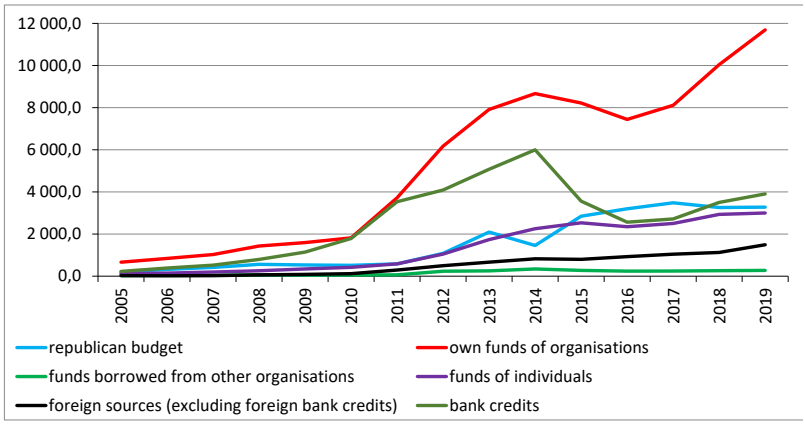

Figure 5. Fixed capital investment in Belarus by source of financing (million belarusian rubles)

Complex trends in the investment sphere of Belarus are due to the peculiarities of the country's socio-economic development. These include:

- low level of development of the financial market, in connection with which enterprises are forced to use their own resources;

- predominance of the state form of ownership in the capital of the banking system;

- low level of interconnection between the banking sector and the real sector of the economy;

- dependence of the volume of foreign investments on the situation in the world commodity and foreign exchange market;

- high susceptibility of the economy to socio-economic and political processes in Russia which remains the main economic partner of Belarus.

In addition, studies of Belarusian scientists confirm that unfavorable tendencies in the Belarusian economy are a consequence of the tendencies of decreasing the efficiency of production factors that have developed in the country over a long period [21].

The revealed features of the investment sphere of Belarus necessitate the identification of effective ways to stimulate the investment process.

\section{Methodology of monetary regulation of investments}

The most general classification of financial regulation methods presented in scientific sources is their division into two groups - fiscal methods and monetary methods. This generalized approach is based on the fundamental findings of Keynesian and monetarist theoretical directions.

Fiscal regulation which includes two directions - tax and budget, has an indirect impact on the development of investment processes at all levels of management. At the national level the tax and budget systems are formed through which the state determines and implements socioeconomic development goals. Rational distribution of the tax burden between legal entities and individuals taking into account the strategic goals of economic development 
Table 1. The structure of fixed capital investment by type of ownership

\begin{tabular}{llllllll}
\hline & 2010 & 2012 & 2014 & 2016 & 2017 & 2018 & 2019 \\
\hline $\begin{array}{l}\text { Total fixed capital investment } \\
\text { on which by }\end{array}$ & 100 & 100 & 100 & 100 & 100 & 100 & 100 \\
- state ownership & 50.0 & 40.0 & 37.0 & 41.0 & 40.7 & 39.5 & 39.0 \\
- private ownership & 47.6 & 53.9 & 54.1 & 51.2 & 51.8 & 52.7 & 51.7 \\
- foreign ownership & 2.4 & 6.1 & 8.8 & 7.8 & 7.5 & 7.8 & 9.3 \\
\hline
\end{tabular}

gives the state the opportunity to accumulate financial flows and direct them to finance priority areas and industries.

Monetary regulation reflects the impact of the central bank on the activities of banks and other credit institutions through monetary instruments and methods. It is associated with changes in the volume and structure of the money supply in the country, interest rates and exchange rates in the credit and foreign exchange markets. The central bank influences money supply and demand and, thus, the degree of investment activity of organizations. The growth or decline of investments in the economy will depend on the cost of resources in the money market. The central bank having legal, organizational and economic powers regulates the value of credit money.

In the context of the globalization of the economy foreign economic regulation is of great importance. It is a tool for influencing participants in foreign economic relations and includes such methods as customs procedures, payments, control and the legally established procedure for interaction between them. Foreign economic regulation is considered as a kind of fiscal regulation which is implemented in the context of the country's participation in international economic relations. A feature of its implementation is the need to coordinate national goals with the functioning of international institutions and the system of organizing world economic relations formed on the basis of international law and interstate agreements. Foreign economic regulation affects the import of goods and services, the export of manufactured goods and services, foreign exchange earnings, as well as the attraction and use of various forms of foreign investment.

Monetary regulation plays an important role in the development of the investment process. The first effect of monetary regulation on investment is short-term. It consists in ensuring optimal operating expenses of organizations and the population which can provide a potential growth in savings. The monetary regulation in this case is aimed at rational management and stimulating investment activity of market entities at the micro level. The second effect of the monetary regulation has a long-term character which consists in creating conditions for attracting domestic and foreign investments. In fact, it is aimed at creating and maintaining the investment climate in the country. This long-term effect is realized at the macro level through the state investment policy.

The advantages of monetary regulation over fiscal regulation are still the subject of scientific controversy. Scientific discussions are built on the basis that along with the positive aspects, monetary policy also has disadvan- tages. In particular, one of the problems of monetary policy implementation is cyclical asymmetry in investment and banking operations. We believe that it is necessary to determine the merits of monetary policy as the basis for the implementation of the state's investment policy.

First, the advantage of monetary policy is its flexibility and efficiency. This means that when external economic, political and other conditions change, monetary policy can be transformed rather quickly taking into account these changes.

The parameters of monetary policy are set by the Central Bank endowed with the necessary powers to make quick decisions. The Central Bank responds promptly to the market situation based on information about the current situation and forecasts of the development of financial markets and the economy as a whole. The Central Bank makes daily decisions on the use of open market operations, changes in reserve requirements, interest rates and other instruments. Thus, it influences the volume and structure of money supply on a daily basis.

The property of efficiency which fully relates to monetary policy cannot be attributed to fiscal one. As is known from practice the implementation of fiscal policy is a rather complicated and cumbersome process. This is due to the fact that making different kinds of decisions such as directions on budget expenditures, changes in tax rates, tax incentives, etc. may be postponed for a long time due to public discussions and approval of these decisions in the legislature.

In addition, the methods and instruments of monetary policy are softer and politically more conservative than those of fiscal policy. For example, an increase in government spending has a direct impact on the volume and structure of the distribution of budgetary resources which are approved by the law on the state budget. Consequently, these changes must be made to the law in accordance with the approved procedure. Tax changes are usually adopted for a long time and require public and parliamentary discussion. However, they can be unpopular and have political consequences. Monetary policy appears to be more politically acceptable, as it indirectly affects the social sphere and vulnerable sectors of society. Influencing the conjuncture of the money market the Central Bank provides the population with an opportunity to choose assets for savings and investment methods.

The second advantage of monetary policy is that Central Banks have so-called political independence from the executive authorities which is seen as a guarantee of the effectiveness of their activities. In world practice it is believed that the most independent is the US Federal Reserve 
System. In most countries of the world central banks report directly to parliament or to a special parliamentary commission. However, it should be understood that the independence of the central bank is relative - it is independence "within the government structures". The political independence of the central bank consists in formal independence from government instructions, legislative prohibition of direct government loans from the central bank, protection of the central bank management from dismissal, and others. This relative freedom makes it easier for the central bank to make the unpopular decisions needed to restore the economy in the long time period than it is for the government.

The independence of the central bank is seen as an important advantage of monetary regulation over fiscal, since the subject of fiscal regulation, the Ministry of Finance, being a government agency by its status expresses the interests of the government which can have a political overtone and contribute mainly to the achievement of shortterm goals.

The third advantage of monetary regulation over fiscal regulation which is considered in the scientific literature is the effectiveness of its impact on economic stability. For example, Russian scientists Zubov and Inozemtsev note that since the monetary regulation mechanism is implemented through banks which are private structures their decisions are more effective (speed of adoption and implementation of decisions) in comparison with government organizations that implement fiscal policy. In private banks and other private credit institutions, responsibility for spending their own funds is personified, and not blurred as when using state (budget) funds [22].

Foreign sources also substantiate the advantages of monetary regulation. So in the work of I. Stiglitz and B. Greenwald [23] it is proved that monetary policy based on the credit paradigm is more effective in terms of impact on the stability of the economy. There are studies that prove that the modern structure of banking systems with large, state-owned banks is highly capable of absorbing the consequences of crisis impacts [24]. These theoretical conclusions are confirmed by empirical data that characterize the tendency to increase the degree of government regulation of banking systems in both developed and developing countries. State regulation in the banking system is ensured by the mandatory presence of the first link in its structure - the Central Bank, as well as the presence of a system of state banks. Moreover, in times of crisis the number and importance of state-owned banks increases.

The fourth advantage of monetary regulation is that the volume of bank investment resources significantly exceeds budgetary financing of the economy. This is due to the fact that the volume of budget financing is limited by the volume of the expenditure side of the budget and has a strictly targeted direction. This conclusion is confirmed by the indicators for the Republic of Belarus, presented in figure 6 [25].

As can be seen from the data presented, the volume of bank lending in the Republic of Belarus consistently exceeds the volume of budget financing by an average of 8-10 times annually.

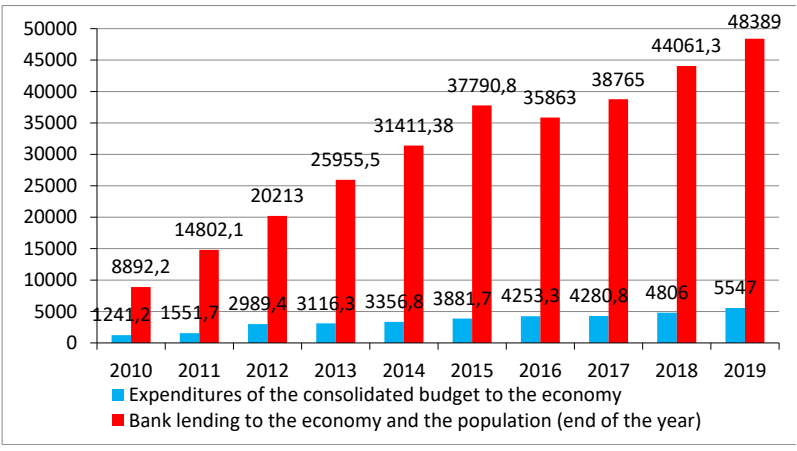

Figure 6. Banking and budgetary investment resources for the economy of the Republic of Belarus (million belarusian rubles)

Modern financial systems of developing countries are largely based, first of all, on the banking (credit) system, which is more developed, concentrated and stable.

\section{Monetary policy strategies and its economic results in the Republic of Belarus}

In world practice the evolution of goals, objectives and strategies of central banks went through three stages starting from the Great Depression of the 1930s. and ending with the Great Inflation period of the 1970s:

- at the first stage the tasks of the central banks were determined by the requirements of the gold standard. The main functions of central banks were to ensure the convertibility of the national currency into gold, ensure the stability of the payment system, and provide loans to government bodies;

- the consequences of the Great Depression focused the attention of central banks on the need to maintain employment and price stability, ensure the stability of the balance of payments and the exchange rate of national currencies;

- lafter the Great Inflation of the 1970s. the main goal of central banks is to achieve price stability.

At present it is reasonable to single out the fourth stage in the evolution of monetary policy the beginning of which was the global financial and economic crisis of 2008-2009.

The consequences of the crisis determined the need for central banks to resolve two key issues: improving the mechanisms of banking regulation and financial supervision and achieving not only price, but also financial stability.

Central banks pursue a policy aimed at creating conditions for long-term sustainable economic growth by ensuring low and predictable inflation. Another important indicator of the conditions for long-term growth is the provision and maintenance of financial stability in the country. From the standpoint of strengthening the investment orientation of monetary policy price stability is necessary for the following reasons: first, it stimulates business to 
long-term planning and implementation of the investment process, since it reduces uncertainty in economic relations. Secondly, it increases confidence in the national currency. If the population does not have confidence in the national currency problems arise with the flow of savings into the banking system. In turn, the decline in the stability of the resource base of banks limits their ability to lend to the economy for a long time. Third, price stability affects the stability of the financial sector, which ultimately leads to the formation of an affordable price for credit resources.

Achieving price stability is based on the central bank's policy to control inflation. This is achieved by regulating the volume of money supply and, accordingly, the credit activity of the banking system. In the scientific literature there is evidence that inflation control is an important, but not the only goal of monetary regulation [26]. As is known from scientific sources and economic practice hyperinflation fetters economic activity, moderate inflation often promotes or accompanies growth, and zero inflation or deflation are companions of depression and subsequent stagnation. A decrease in inflation may be associated not only with an increase in economic activity which is a positive result, but also with a drop in consumer demand for goods and services, as well as a low level of lending to the real sector of the economy. Therefore, it is inappropriate to assert that the main task of monetary policy is exclusively to control inflation since with this approach it can turn into a brake on economic growth.

In order to substantiate the type of monetary policy strategy that best affects the growth of investments in the Republic of Belarus it is necessary to analyze the target strategies of the National Bank. So, in the period 20002011 in the Republic of Belarus the exchange rate targeting regime was applied and from 2012 to 2014 this strategy was applied in combination with inflation control. During this period was carried out a policy aimed at stimulating domestic demand through credit expansion. At the same time it was supplemented by active budget support from the public sector and a soft wage policy which led to the formation of significant macroeconomic imbalances. As a result, the possibilities of further application of the exchange rate targeting regime were exhausted after the currency crisis of 2011 and the external shock of 2014.

A special stage in the economic development of Belarus is occupied by the favorable period of 2005-2010 when the growth of investments was $120 \%$ in $2005,132 \%$ in $2006,117 \%$ in $2007,123.5 \%$ in 2008 and $115.8 \%$ in 2010 compared to the previous year. The share of fixed capital investments in GDP increased from $23.2 \%$ in 2005 up to $33.7 \%$ in 2010 . According to international organizations high growth in this period in Belarus was achieved mainly due to the rapid accumulation of fixed capital. This became possible due to the high ratio of investment to GDP (the growth of fixed assets based on a high share of investment in GDP accounted for approximately 70\%) [27]. However, during this period there was a bias in favor of building and assembly works as a result of the implementation of government programs for housing construction while the growth of investments in machinery and equipment in 2009 turned negative. Based on the

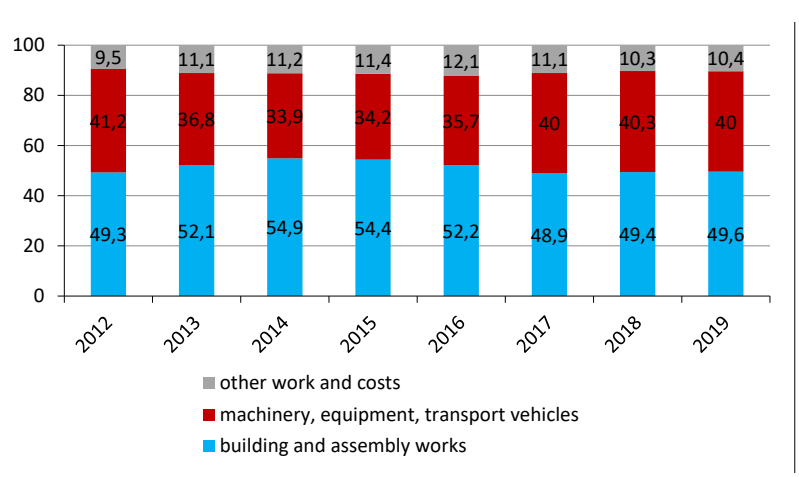

Figure 7. The structure of fixed capital investment in Belarus $(\%)$

theoretical concept of endogenous growth developed in the second half of the 1980s capital accumulation (especially investments in technological innovation) is considered the most important determinants of long-term economic growth [28]. As a result of the research scientists have proven that the ratio of investment in machinery and equipment to GDP has a positive effect on economic growth. At the same time some scientific sources proved that the share of investment in housing (building and assembly works) in GDP does not have a significant effect on economic growth [29]. Figure 7 shows the structure of fixed capital investments in the Republic of Belarus from which it can be seen that almost half of the investments are just building and assembly works. The share of investments in machinery and equipment varied slightly from $33.9 \%$ (2014) to $41.2 \%$ (2012) and $40 \%$ in 2019 which indicates the absence of progressive changes in this indicator [19].

In the early 2000s there was an artificial stimulation of investment. This was reflected in the infusion of large sums of money into the economy in the form of directed loans, as well as in the form of a large volume of housing construction. Such artificial stimulation has become the main source of high rates of economic growth. High investment activity distinguished this period from subsequent ones and continued until the global financial and economic crisis of 2008-2009. Then the main destabilizing factor was the drop in demand for Belarusian products in foreign markets. The financial results of the organizations' work have worsened. The rate of GDP growth began to decline [30]. The monetary policy pursued at that time by the National Bank of the Republic of Belarus was based on the exchange rate strategy which contributed to economic growth until 2011.

Over the next 2011-2015 the Belarusian economy functioned in unfavourable external conditions which, first of all, were predetermined by the slowdown in economic growth in Russia which is the main economic partner of the Republic of Belarus.

Since 2010 the policy of stimulating economic growth with monetary and fiscal policy instruments has been resumed which limited the effectiveness of stabilization measures and exacerbated the existing imbalances. This 
led to an increase in the current account deficit of the balance of payments to $14.5 \%$ of GDP and led to a significant adjustment in the nominal exchange rate of the Belarusian ruble to the US dollar in 2011 [31].

In 2012 the economy returned to a state of temporary stabilization. This was due to an exchange rate adjustment and a significant increase in the export of petrochemical goods to the EU countries and the machine-building goods to Russia. Despite the presence of obvious imbalances in the economy, further economic policy focused on increasing domestic demand and stimulating production, which required external borrowing.

In 2013 the volume of GDP in Belarus increased by $1 \%$ in comparable prices and was provided by expanding domestic demand, which contributed to the accelerated formation of added value in retail trade and construction. The increase in activity in these segments was due to a fairly high household incomes growth and a fixed capital investment increase. At the same time there was a noticeable decrease in production volumes in industry (primarily in its export-oriented industries) and agriculture of the country.

In 2014 real GDP growth in the Republic of Belarus amounted to $1.6 \%$. The national economy growth was due to the recovery in industrial production which was achieved through an increase in the production of the petrochemical, chemical and mining industries. At the same time observed a slowdown in the household income growth and a decline in fixed capital investment.

A decrease in the capacity of traditional sales markets for domestic products and an unfavourable pricing environment for exported goods led to a sharp decline in exports (compared to 2012 by almost 20\%). This led to a negative trade balance of $\$ 10.2$ billion (in total for 20132014). This, in turn, created an additional burden on the domestic foreign exchange market and limited the ability to maintain the exchange rate stability of the national currency.

The deterioration of the macroeconomic environment had a negative impact on the financial results of the functioning of the real sector of the economy. For 2014-2015 the number of unprofitable organizations in the country increased 2.7 times, and the total value of their net loss increased 3.9 times. Agriculture was among the sectors that most acutely faced the growing financial problems: in 2015 (compared to 2012) the number of unprofitable agricultural enterprises increased 4.9 times, and the total amount of their loss increased 10.7 times.

In 2014 two loans were received from the Russian Government for a total of $\$ 2.0$ billion. In 2015 two more loans were received in the amount of $\$ 870$ million which helped to support GDP growth.

Monetary policy based on the exchange rate strategy in the Republic of Belarus in the period 2000-2014 in the context of accelerated economic growth and declining efficiency of accumulation had negative consequences.

Such growth prompting the resort to excessive emission lending to business entities and external borrowing negatively affects the state of the country's financial system, does not stimulate investment activity. In the future this trend continued. However, according to the Belarusian scientist and the practice of the monetary sphere D. Kalechits, the reason for the low rates of equilibrium GDP is explained not so much by the expansionary monetary policy as by the fall in the return on factors of production. This is confirmed by the fact that the average contribution of total factors of production to GDP decreased from $4.1 \%$ in 2001-2009 down to minus $0.5 \%$ in 2010-2018 [32].

Structural weaknesses constrain economic growth and thereby increase the vulnerability of a country's economy to the crisis. After the initially successful stabilization of the post-crisis 2011 in 2012-2014 a policy of alternating stimulating and restraining economic measures was implemented This was mainly expressed by an increase in wages and an increase in directed lending, did not lead to the restoration of stability, and inflation remained at a high level [16] (figure 8).

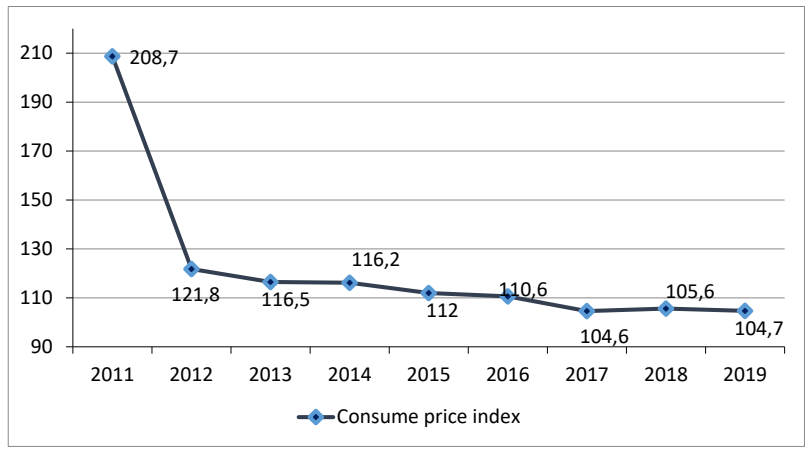

Figure 8. The trend of consumer price index in Belarus (December to December of previous year) $(\%)$

One of the rational steps of the central bank in the following years was the monetary policy aimed at the development of the financial sector, as well as at its orientation towards the long-term development of the Belarusian economy. Since 2015 the National Bank has been implementing a monetary targeting strategy which is based on the thesis of the quantitative theory of money: in the long term the growth of commodity prices is determined solely by the supply of money.

A significant deterioration in external economic conditions in 2015 caused by the fall in world prices for raw materials, as well as geopolitical tensions led to a decrease in economic activity in Russia and Ukraine, a sharp drop in investment demand, and devaluation of national currencies in the EAEU member states. This led to a drop in Belarus' GDP in real terms by $3.8 \%$. Subsequently, the situation improved slightly until 2018 but in 2019 there was a decrease in GDP growth rates from 3 to $1.2 \%$ [16] (figure 9).

In 2016 Belarus was launched a three-year program of the Eurasian Fund for Strategic Development providing for a financial loan of $\$ 2$ billion. In 2017 the Russian Government provided a loan to the Republic of Belarus for refinancing the external public debt in the amount of $\$ 700$ million. In addition, in June 2017 Belarus placed a double tranche of Eurobonds in international capital markets for a total of $\$ 1.4$ billion. 


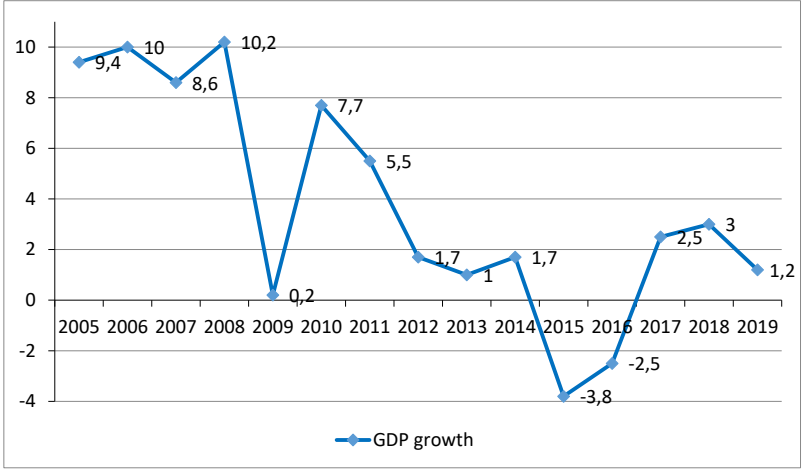

Figure 9. Gross Domestic Product in Belarus (at constant prices, percent to the previous year)

During 2017 sustained economic growth (102.5\%) and a reduction in the current account deficit were achieved.

Leverage was actively used to attract external investment resources in the form of foreign investment. This policy, however, entailed a significant growth of external debt. The external public debt of the Republic of Belarus as of 01.01.2019 increased to 39288.8 million US dollars which amounted to $65.9 \%$ of GDP against $18.5 \%$ in 2007 [33].

In 2015-2018 the National Bank pursued a tough emission policy. The credit issue was carried out exclusively within the framework of using standard bank refinancing operations at market interest rates and for short periods.

The monetary targeting strategy in the Republic of Belarus had positive results such as stabilization of the economy, partial improvement of the main macroeconomic indicators. Nevertheless, there were no fundamental changes in the development of the investment process and economic growth during this period. Table 2 shows the results of the National Bank's credit issue in order to stimulate economic growth at various stages of monetary policy.

As can be seen from the data presented in the table 2 the expansionary monetary policy pursued in the Republic of Belarus had different results for inflation and the exchange rate. The best period can be considered 2004-2007 when the growth of money supply contributed to economic growth through improved conditions for economic activity (relative stability of prices and exchange rates) (figure 9). The next two periods when the National Bank used the exchange rate strategy in combination with maintaining low inflation had negative results, such as high inflation and devaluation of the Belarusian ruble. In the period from 2008 to 2015 external economic factors had a significant impact on the domestic economic situation: the global financial crisis and the decline in demand for Belarusian products in Russia after 2014. The monetary targeting policy implemented in the country since 2016 demonstrated the achievement of price and currency stability which positively influenced the investment activity of organizations and the population and, accordingly, was reflected in the indicators of economic growth.
The National Bank of the Republic of Belarus plans to apply a monetary targeting strategy was carried out until 2020 which created the basis for the transition to 2021 . The inflation targeting regime in international practice is recognized as the most effective tool for managing inflation expectations of economic entities, thereby acquiring a long-term nature. A distinctive feature of this regime is a clear and transparent definition of the goals and priorities of monetary policy, its openness for all economic agents. This contributes to the formation of favourable expectations of the population and business, increases their confidence in the central bank and its monetary policy.

The transition to an inflation targeting strategy in the Republic of Belarus is provided for by the Program of the country's socio-economic development for the new fiveyear period 2021-2025. In this regard, since 2015 the National Bank has already implemented a number of measures to form the initial economic conditions for the implementation of this strategy. Among them is the transition to flexible exchange rate formation. A floating rate is especially necessary in case of deterioration of external conditions, since it is the exchange rate that assumes the main negative consequences, thereby protecting the domestic financial market and the economy.

Along with achieving price stability another monetary goal for long-term growth is to ensure financial stability which is a prerequisite for low inflation and unemployment. In the economic literature "financial stability refers to the state of the financial system in which banks and nonbank financial institutions, other financial intermediaries, the payment system and the financial market properly perform their inherent functions and retain the ability to perform them in the event of the destabilizing impact of internal and external factors" [34].

The stable development of the financial sector includes measures to strengthen the degree of state regulation in the financial market which was implemented in the activities of central banks in the following areas:

A. Reorienting the objectives of central banks. Since the post-crisis period a transition in the activities of central banks from solving purely monetary problems to general economic ones has been planned. General economic objectives are designed to solve the problems of improving the financial and investment climate, thereby contributing to financial stability, sustainability and economic growth.

B. Reducing the degree of freedom and autonomy of central banks. The provisions on the need for stricter regulation of the activities of central banks and strengthening their interaction with the government were developed. At present the central bank is becoming not so much an economic as a political and partly ideological institution. At the national level in developed countries a new function of the central bank is to provide financial assistance and support to banks and other financial companies.

C. Concentration of supervisory functions in one place and creation of a single mega-regulator of the financial 
Table 2. The results of monetary policy strategies of the National Bank in the Republic of Belarus

\begin{tabular}{lllll}
\hline Period & The aim of monetary policy & Emission growth (\%) & $\begin{array}{l}\text { Consumer price } \\
\text { index growth }(\%)\end{array}$ & Exchange rate trend (\%) \\
\hline $2000-2003$ & Exchange rate & $+819,0 \%$ & $+194,97 \%$ & - \\
$2004-2007$ & Exchange rate & $+336,45 \%$ & $+27,93 \%$ & $-0,66 \%$ \\
$2008-2011$ & Exchange rate & $+132,73 \%$ & $+86,6 \%$ & $+116,43 \%$ \\
$2012-2015$ & Exchange rate and inflation & $+110,09 \%$ & $+58,6 \%$ & $+90,32 \%$ \\
$2016-2018$ & Money supply & $+101,62 \%$ & $+11,1 \%$ & $+2,42 \%$ \\
\hline
\end{tabular}

market. In the process of development of the financial market the deepening of specialization of individual financial transactions and tools has led to the emergence of multiple organizational forms of autonomous state supervisory and regulatory institutions. Among them such as the Central Bank, the Securities and Stock Exchange Commission, the Commodity Exchange Commission, the Deposit Insurance Corporation, the Mortgage Lending Commission, etc. Each country has developed its own system of state organizations associated with the regulation of individual segments of the financial market. A situation arose when several government institutions controlled the financial market which accordingly led to inconsistency in their actions and results. In the process of reforming the financial system after the crisis of 2008 the functions of the mega-regulator of the national financial markets were gradually legislatively assigned mainly to the Central Bank of the country.

Macroprudential policy of the National Bank plays a key role in maintaining financial stability. This policy solves the following tasks:

- encouraging financial intermediaries to build up additional capital and liquidity reserves in advance for those times when they may be required;

- adjustment and alignment of credit flows in the economy. An imbalance can cause not only a shortage of credit resources but also their excess. Unequal distribution and wasteful use of bank loans (when they are cheap and available) can disrupt the financial market and cause instability;

- stimulating the efficient distribution of financial resources in the economy. There is always the possibility that resources will be directed to those economic entities that will not be able to pay off their obligations. Detecting and correcting such distortions can reduce financial risks;

- increasing the stability of the financial infrastructure, limiting the level of concentration of risks in certain segments, and preventing possible situations of liquidity shortage in the financial market.

Macroprudential policy has an obvious advantage: it helps to reduce risks precisely in problem segments, as it acts point-wise maintaining macro-financial stability and minimally affecting the economic growth.

\section{Conclusions}

The results of the analysis of the investment sphere, the stages of evolution of monetary policy, its types and strategies in the Republic of Belarus in the period 2000-2019 allow us to conclude that:

- in developing economies which are characterized by a deficit of domestic investment, insufficient foreign investment, and low rates of development of the investment sphere in general, monetary methods and instruments should be actively used to solve long-term tasks of investment development and create favourable conditions for stimulating investment. The monetary policy of the Central Bank is aimed at creating and maintaining price and financial stability which ultimately form the conditions conducive to attracting investment in the economy;

- the choice of strategies (targets) and types (monetary expansion or restriction) of monetary policy which are established and supported by the Central Bank demonstrates the different nature of their impact on price and financial stability, as well as on the results of economic development as a whole. For Belarus the monetary targeting policy implemented since 2016 demonstrated the achievement of the best indicators of price and currency stability which positively influenced the investment activity of organizations and the population and, accordingly, was reflected in the indicators of economic growth;

- for countries with small open economies such as Belarus the long-term investment effect of the national monetary policy is largely determined by external economic factors and the situation in the foreign exchange market which have now become unfavourable due to the increased epidemiological and political risks in the world and in the country.

\section{References}

[1] J.M. Keynes, The quarterly journal of economics $\mathbf{5 1}$, 209 (1937)

[2] J.R. Hicks, The Economic Journal 49, 696 (1939)

[3] M. Friedman, in Corporate ethics and corporate governance (Springer, 2007), pp. 173-178

[4] B.S. Bernanke, T. Laubach, F.S. Mishkin, A.S. Posen, Inflation targeting: lessons from the international experience (Princeton University Press, 2018)

[5] P.A. Samuelson, in The world scientific handbook of futures markets (World Scientific, 2016), pp. 25-38 
[6] J. Tobin, Journal of money, credit and banking 1, 15 (1969)

[7] E. Dorina, E. Kadovba, University Economic Bulletin pp. 47-57 (2019)

[8] V.N. Shimov, Problems of Economic Transition 48, 10 (2005)

[9] S.Y. Glazyev, Russia and new world order. Strategy of economic growth on a threshold of the XXI century pp. 164-165 (1997)

[10] L. Krasavina, Studies on Russian Economic Development 21, 426 (2010)

[11] G.I. Idrisov, V.N. Knyaginin, A.L. Kudrin, E.S. Rozhkova et al., Voprosy Economiki 4 (2018)

[12] S.R. Moiseev, Voprosy Ekonomiki pp. 112-122 (2019)

[13] L. Krasavina, A. Galchinskiy, V. Shenaev, Monetary circulation and credit under capitalism (1989)

[14] O.I. Rumyantseva, Belarusian Economic Journal 2, 61 (2014)

[15] Exchange portal TAKE-PRIFIT.BY, Rating of countries by money supply M2 (2018), https://take-profit.org/statistics/ money-supply-m2/

[16] I. Medvedeva, ed., Statistical Yearbook of the Republic of Belarus (National Statistical Committee of the Republic of Belarus, Minsk, 2019), p. 472

[17] Macroeconomics and finances of the CIS and other countries of the world 2014-2018: statistical review (Interstate stat. com. Commonwealth of Independent States, Moscow, 2019), p. 59

[18] National Bank of the Republic of Belarus, Direct foreign investments (2018), http: //www . nbrb . by/ statistics/foreigndirectinvestments

[19] I. Medvedeva, ed., Investment and construction in the Republic of Belarus: statistical review (National Statistical Committee of the Republic of Belarus, Minsk, 2019), p. 134

[20] National Statistical Committee of the Republic of Belarus, Investments in fixed capital (2018), http://www.belstat. gov.by/ofitsialnaya-statistika/ realny-sector-ekonomiki/ investitsii-i-stroitelstvo/ investitsii-v-osnovnoy-kapital/ godovye-dannye/

[21] V.N. Komkov, Bankauski Vesnik 29 (2011)

[22] V. Inozemtsev, V.M. Zubov, Problems of Economics 3, 76 (2015)

[23] J.E. Stiglitz, B. Greenwald, Towards a new paradigm in monetary economics (Cambridge Univ. Press, Cambridge, 2003)

[24] A. Yudanov, Experience of competition in Russia: reasons for success and failure (KnoRus, Moscow, 2008)

[25] I. Medvedeva, ed., Statistical Yearbook of the Republic of Belarus (National Statistical Committee of the Republic of Belarus, Minsk, 2020)

[26] M. Ershov, Economic Issues 12, 4 (2010)

[27] E. Trofimova, Banking systems of the cis countries: different perspectives but common risks (2004), http://data.cbonds.info/comments/ 8055/CIS_banks_Q21204_R.pdf

[28] P. Romer, Journal of Political Economy XCIV, 1002 (1986)

[29] H. Jalilian, M. Odedokun, Applied Economics 32, 289 (2020)

[30] E. Petrovich, Economic Bulletin of the NIEI of the Ministry of Economy of the Republic of Belarus 6, 4 (2016)

[31] M.N. Vlasenko, Belarusian Economic Journal 3, 43 (2018)

[32] D. Kalechits, Transformation of the goals of the National Bank at the present stage, in Intern. Scientific and practical conf. Economic growth of the Republic of Belarus: globalization, innovation, sustainability (BSEU, Minsk, 2019), http://www.nbrb.by/top/pdf/ transformaciya-celej-deyatelnosti-kalechits. pdf

[33] National Bank of the Republic of Belarus, Gross external debt of the Republic of Belarus (2020), http: //www.nbrb.by/statistics/externaldebt

[34] S. Kalechits, Bankauski Vesnik 3, 8 (2019) 